Journal of Business and Management Studies (JBMS)

ISSN: 2709-0876

DOI: $10.32996 / \mathrm{jbms}$

Journal Homepage: www.al-kindipublisher.com/index.php/jbms

\title{
Factors Affecting Corporate Bond Ratings in Indonesia
}

\author{
Ruspriono ${ }^{1}$ (D) $\triangle$ and Bambang Santoso Marsoem ${ }^{2} \mathbf{8}$ \\ ${ }^{12}$ Master of Management, Mercu Buana University, Indonesia \\ $\triangle$ Corresponding Author: Ruspriono, E-mail: ruspriono@gmail.com
}

\section{ARTICLE INFORMATION}

Received: July 11, 2021

Accepted: August 20, 2021

Volume: 3

Issue: 2

DOI: $10.32996 / j b m s .2021 .3 .2 .10$

\section{KEYWORDS}

Bond Rating, Liquidity, Activity, Leverage, Profitability, Maturity, Auditor Reputation

\section{ABSTRACT}

Bonds provide a rating signal for the issuer and investors of the ability to pay off a bond. This study aims to explain the factors that affect the ranking in terms of accounting and non-accounting aspects. This study uses all corporate bonds actively traded on the Indonesia Stock Exchange (IDX) and are denominated in rupiah as of December 31, 2019, sourced from Bloomberg, which consists of 996 companies. The method in the sample is the purposive sampling method. This sample consists of 35 companies with 111 bonds, testing the hypothesis using ordinal logistic regression analysis with SPSS Version 25.0 data processing tools. The results showed that liquidity had a positive effect on bond ratings, activity does not affect bond ratings, leverage, profitability, maturity, and auditor reputation have a negative effect on bond ratings.

\section{Introduction}

The high interest of investors in investing in bonds has increased. In 2015, 103 companies issued bonds, and in 2019 there were 119 companies or grew by $2.93 \%$ for 5 years. Total outstanding bonds in 2015 amounted to Rp187.65 trillion and in 2019 , Rp388.43 trillion or grew $15.66 \%$ for 5 years.

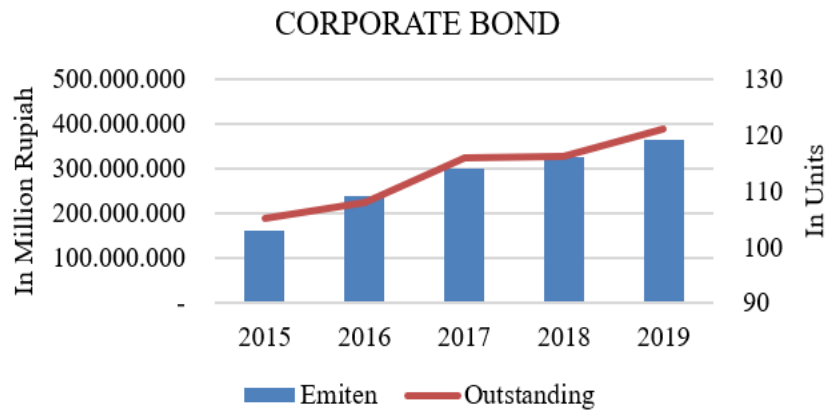

Figure 1. Corporate Bonds in Indonesia

Source: OJK, Capital Market Statistics, IDX.

Defaulting bonds became the attention of investors where some companies or issuers delayed payment of debt and interest from the schedule, and this gave negative sentiment. Several companies are experiencing cash flow difficulties due to the Covid 19 pandemic, one of which is a drastic decline in revenue which can increase the risk of default on maturing bonds. The potential risk of default in Indonesia has increased due to the Covid-19 pandemic based on information from PT Pemeringkat Efek Indonesia (Pefindo).

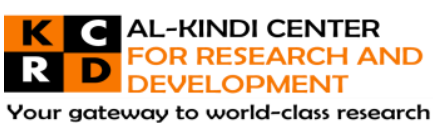

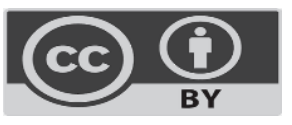

Published by Al-Kindi Center for Research and Development. Copyright (c) the author(s). This open access article is distributed under a Creative Commons Attribution (CC-BY) 4.0 license 
Table 1. Annual Default Rate

\begin{tabular}{|l|c|c|}
\hline \multirow{2}{*}{ Year } & \multicolumn{2}{|c|}{ Default Rate } \\
\cline { 2 - 3 } & Companies & Bond \\
\hline 2015 & $2,31 \%$ & $0,79 \%$ \\
\hline 2016 & $2,08 \%$ & $0,61 \%$ \\
\hline 2017 & $2,40 \%$ & $0,52 \%$ \\
\hline 2018 & $3,91 \%$ & $0,92 \%$ \\
\hline 2019 & $3,72 \%$ & $0,79 \%$ \\
\hline
\end{tabular}

Sources: Pefindo

The debt default rate in 2019 decreased from $0.92 \%$ in 2018 to $0.79 \%$ at the end of 2019 , while based on the issuing firm, the default rate fell from $3.91 \%$ at the end of 2018 to only $3.72 \%$ at the end of 2019 (Pefindo, 2020). In the third quarter of 2020, Pefindo noted that as many as three companies were at risk of default. PT Modernland Realty Tbk (MDLN) defaulted on a maturing debt of Rp150 billion on July 7, 2020. Pefindo gave an idSD rating due to the default on bonds denominated in USD, while bonds denominated in rupiah rose to CCC, the increase in the MDLN rating was due to an agreement between bondholders and bond issuers to reduce the interest rate to $10 \%$ from $12.5 \%$ and extended the maturity duration for 1 year to 7 July 2021 (Kontan, 2020). PT. Tiphone Mobile Indonesia Tbk officially has the status of Temporary Debt Payment Obligation after PT. Tiphone Mobile Indonesia Tbk defaulted on its syndicated bank bonds and loans.

Default risk is the biggest risk in investing in bond instruments, where principal and interest are not paid on bonds due to financial distress, so an analysis of bond ratings is important in minimizing the risks that will occur. Investors and issuers need to evaluate and analyze the factors that affect bond ratings to minimize the risks that will occur and optimize bonds. Based on this, the researchers analyzed several problems that could affect bond ratings. Liquidity through the Current Ratio (CR) can be done by comparing current assets with current liabilities. The higher the $C R$, it means that the more current assets can cover all current liabilities. CR has a positive effect on bond rating (Faradi \& Supriyanto, 2015). CR has a negative effect on bond ratings (Rudi \& Marsoem, 2019), while CR does not affect bond ratings (Rosa \& Musdholifah, 2016). Activity ratio is a ratio used to measure the level of efficiency in utilising company resources (sales, inventory, collection of receivables, and others) or a ratio to assess the company's ability to carry out daily activities. According to (Kasmir, 2016) Total Assets Turnover (TATO) is a ratio based on asset management dividing sales by total assets. Large assets can be used as collateral to pay off debts. Leverage using the Debt-toEquity Ratio (DER) can be done by comparing debt to equity. According to (Sihombing, 2018), DER shows the relative claims of creditors and shareholders on firm assets or the relative proportion between debt and equity in financing firm assets. DER has a positive effect on bond ratings (Mardiyati, Utami, \& Ahmad, 2015), DER negatively affects bond ratings (Rudi \& Marsoem, 2019). Profitability is measured through Return on Assets (ROA), where ROA proves the amount of contribution based on an asset in forming profits. The increased ROA proves that the use of assets can form profits, and therefore a positive signal for investors to invest in the firm. (Rudi \& Marsoem, 2019) and (Sahabbudin \& Hadianto, 2020) state that ROA has a positive effect on bond ratings. (Utami, Diah Anitasari, \& Endhiarto, 2017) \& (Parulian \& Suprihatin, 2020) stated that ROA does not affect bond ratings. Maturity is the period from the bonds issued until the bonds expire (Brigham \& Houston, 2018) stated that positive maturity affects bond ratings, so it can be said that the bonds with short-term maturity have a higher bond rating than long-term maturity, while (Sakinah, Paminto, \& Kadafi, 2017) states that negative maturity effect on bond ratings and (Pratama \& Andhitiyara, 2020) stated that maturity does not affect bond ratings. Public Accounting Firm (KAP) services are used by companies to submit reports containing financial information to the public, generally from Big Four KAPs, and have investmentgrade bonds. The higher the reputation of the auditor can provide a level of comfort and trust so that it can have an impact on the smaller the possibility of failure. Research (Asih, DP, \& Silalahi, 2016) states that auditor reputation significantly influences bond rating predictions.

Phenomena and research gaps from previous studies on several independent variables that have contradictory results so that researchers analyze factors that can influence bond ratings. The author limits the problem by only reviewing accounting aspects, namely liquidity, activity, leverage, profitability, and non-accounting, consisting of maturity and auditor reputation on corporate bonds in 2019.

\section{Literature Review}

\subsection{Bond Rating}

According to (Wijaya, 2017) "bonds are medium to long-term debt securities that can be transferred and contain a commitment from the bond issuer to pay and pay off interest or coupons from the bond issuer for a certain period. A bond is a contract designated by the lender and given by the lender as collateral. The value of the bond is the present value of the expected cash 
flows of the bond." In general, a bond's rating is an indicator of the quality and safety of a bond based on the financial status of the issuer of the bond. The bond rating is a rating that indicates that the bond issuer will repay the debt and interest on a timely basis. The purpose of the rating is to provide an overview of the financial performance and terms and conditions of bond issuers through the rating results which are intended as a reliable source for potential investors. This assessment can be changed, revoked, or postponed due to changes in the firm. Bond-rating agencies are organizations that can provide ratings, including Standard and Poor's, Moody's, Fitch, and Pefindo.

\subsection{Credit Risk}

Bond product risk is credit risk. Credit risk is the default of other parties, including debtor default risk, credit concentration risk, counterparty risk, credit risk, and payment risk. The main indicator of credit risk is the bond rating. If the issuer has a high bond rating, the less likely the bond will default. So, it is important to analyze bond ratings where investors seek information about rating changes as a measure of the health of the issuer, while issuers must pay attention to factors that can cause changes in bond ratings to minimize and optimize risk when planning bond issuance. Credit risk is defined as the risk caused by customers and/or other parties' failure to fulfil their obligations.

\subsection{Asymmetric Information}

Asymmetric information was first described in an article (Arrow, 1963) on health care in the American Economic Review, Uncertainty Economics of Welfare and Healthcare. On the other hand, the term asymmetric information is used by (Akerlof, 1970). He said that products classified as good quality also tend to have the lowest average price on the market. Evil sellers try to trick buyers into making the products they sell beautifully. This leads to adverse selection. Adverse selection is a method of making decisions based on weak information. Therefore, buyers avoid fraud by refusing to trade in this market or by spending large sums of money. Therefore, a seller who sells a very good product cannot sell because only buyers think it is cheap, and eventually, the market is flooded with poor-quality products.

\subsection{Signaling Theory.}

Signalling theory is based on the assumption of asymmetric information between managers and investors. In this hypothesis, business leaders seek to inform market investors about their prospects (Megginson, 1997). The same thing is shown by (Ross, 1977) who developed a debt search model in capital structure. Ross concludes from his research that the phenomenon of corporate debt is a good indicator of the firm's consistency with the market and that higher leverage indicates that the firm's management is confident in the firm's future.

\subsection{Agency Theory}

Agency theory explains that there is a cooperative relationship between shareholders and management as an agent in a firm. Agency theory, according to (Jensen \& Meckling, 1976) "one or more contracts in which the agent provides various services on behalf of the agent who delegates decision-making authority to the agent. Managers do not always act under the wishes of shareholders."

\subsection{Liquidity, Activity, Leverage, and Profitability}

Liquidity using the Current Ratio (CR) proxy according to Kieso, Weygandt, \& Warfield (2015) "the lower the current ratio, the weaker the ability to pay a short-term debt of a firm. Suppose a firm's ability to pay a short-term debt is low. In that case, the firm's ability to pay a long-term debt is also low, and there is a risk of bankruptcy." Activity using the Total Assets Turnover (TATO) proxy according to (Kasmir, 2016) Activity with TATO is "the most up-to-date asset management ratio that measures sales of all firm assets, dividing revenue by total assets. Large companies have relatively large amounts of assets, which can be used as collateral to pay off liabilities." Leverage is measured through the Debt-to-Equity Ratio (DER) by comparing debt to equity. According to (Sihombing, 2018), DER shows a relative claim based on creditors \& shareholders to firm assets or the relative ratio of liabilities to equity in financing firm assets. Profitability through Return on Assets (ROA), where ROA shows the contribution of assets in generating net income. "This ratio is calculated by dividing net income by total assets" (Hery, 2016). The higher the ROA, the greater the ability of the business to generate profits based on the use of assets, as a result, investors will see this ability as a positive sign and will encourage investors to increase their dreams to invest in the firm.

\subsection{Maturity and Reputation Auditor}

Bonds have a maturity date since they were first issued. Bonds in financial position are classified as long-term debt and bonds with maturities of less than one year are recognized as short-term debt. On the other hand, buyers of bonds (investments) record as investment assets. The role of the auditor is needed because financial statements must contain reliable information for users of financial statements. A good auditor reputation can provide reliable audit output. Companies audited by auditors who have a high reputation will provide better and more reliable news quality. This is generally indicated by using a large public accounting firm known as the Big Four Worldwide Accounting Firm. 


\section{Methodology}

\subsection{Research Model and Hypothesis}

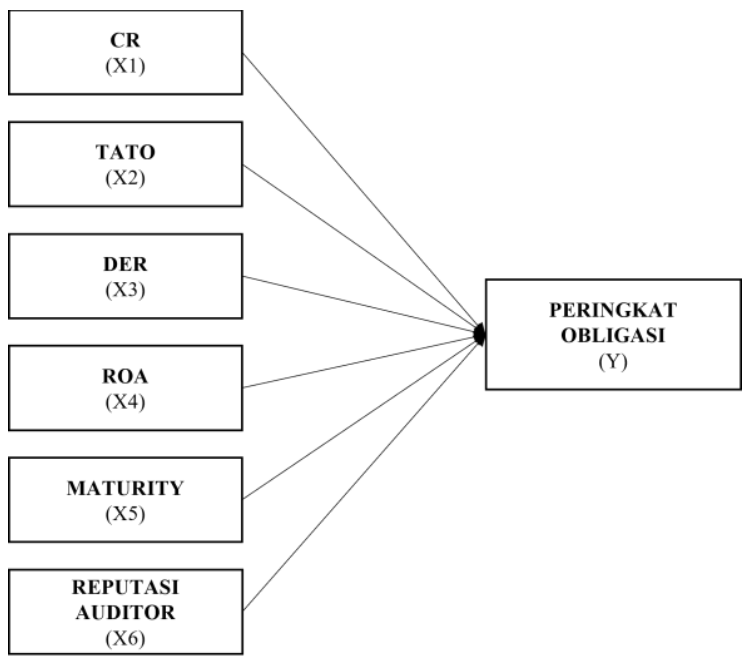

Figure 2. Research Model

Hypothesis:

$\mathrm{H}_{1}$ : Liquidity has a positive effect on bond ratings

$\mathrm{H}_{2}$ : Activity has a negative effect on bond ratings

$\mathrm{H}_{3}$ : Leverage has a positive effect on bond ratings

$\mathrm{H}_{4}$ : Profitability has a positive effect on bond ratings

$\mathrm{H}_{5}$ : Maturity has a negative effect on bond ratings

$\mathrm{H}_{6}$ : Auditor Reputation has a negative effect on bond ratings

\subsection{Research Data and Sample}

Data used in this research is taken from secondary data sources. This study uses all corporate bonds up to December 31, 2019, on the Indonesia Stock Exchange (IDX) sourced from Bloomberg consisting of 996 companies whose financial statements were obtained on the Indonesia Stock Exchange (www.idx.co.id) and bond ratings were obtained issued by Pefindo. The method used in selecting the sample is the purposive sampling method, namely the sampling method based on established criteria. Based on this research, 35 companies have 111 investment-grade bonds. The dependent variable in this study is the bond rating which is measured using an ordinal scale according to Pefindo. This study uses data processing tools "Microsoft Excel \& SPSS version 25.0."

\begin{tabular}{cc}
\multicolumn{2}{c}{ Table 2. Bond Rating Scale } \\
\hline Scale & Symbol \\
\hline 1 & AAA \\
\hline 2 & AA+ \\
\hline 3 & AA \\
\hline 4 & AA- \\
\hline 5 & A + \\
\hline 6 & A \\
\hline 7 & A- \\
\hline 8 & BBB + \\
\hline
\end{tabular}

\subsection{Data Analysis Method}

This research is quantitative descriptive research. Based on theoretical studies and previous research, the variables in this study are liquidity, activity, leverage, profitability, bondage, and auditor reputation as independent variables. In contrast, the bond rating is the dependent variable. Therefore, the research design formed is as follows: 


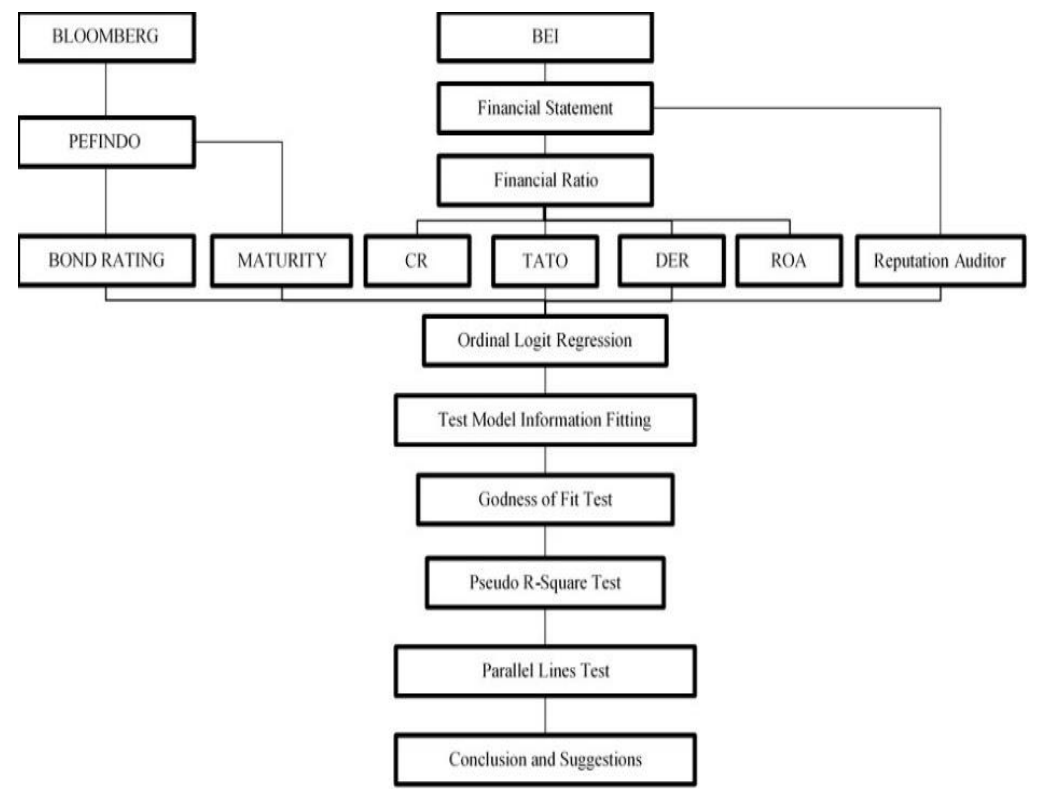

Figure 3. Research Design

This research is causality in which to test the hypothesis about the effect of one or more variables (independent variable) on other variables (dependent variable). The following is a summary of each variable.

Table 3. Variable Operational Summary

\begin{tabular}{llll}
\hline \multicolumn{1}{c}{$\begin{array}{c}\text { Types of } \\
\text { Variables }\end{array}$} & \multicolumn{1}{c}{ Description } & \multicolumn{1}{c}{ Formula (Information) } & Scale \\
\hline Dependent & Bond Rating & The rating issued by Pefindo & Ordinal \\
\hline \multirow{2}{*}{ Independent } & Liquidity & Current Asset / Current Liabilities & Ratio \\
\cline { 2 - 4 } & Activity & Total Sales / Total Asset & Rasio \\
\cline { 2 - 4 } & Leverage & Total Liabilities / Total Equity & Ratio \\
\cline { 2 - 4 } & Profitability & Earning After Tax / Total Asset & Ratio \\
\cline { 2 - 4 } & Maturity & Bond maturity date minus the date & Ordinal \\
& & of a research study. & \\
\cline { 2 - 4 } & Reputasi Auditor & $\begin{array}{l}\text { Auditor other than Big 4 } 0 \\
\text { Auditor Big 4 = 1 }\end{array}$ & Ordinal \\
& & Aun & \\
\hline
\end{tabular}

The data analysis method in this study uses the ordinal logit regression method. This method allows one category to take a certain value. This category is known as the base. A typical logistic regression coefficient for the basic logit model is:

$$
\operatorname{Ln}\left(\frac{p}{1-p}\right)=a+b_{1} X_{1}+b_{2} X_{2}+b_{3} X_{3}+b_{4} X_{4}+b_{5} X_{5}+b_{6} X_{6}+e
$$

Where:

$$
\begin{aligned}
& \operatorname{Ln}\left(\frac{p}{1-p}\right)=\quad \text { Bond rating } \\
& \mathrm{X} 1=\text { Liquidity (CR) } \\
& \mathrm{X} 2=\text { Activity (TATO) } \\
& \mathrm{X} 3=\text { Leverage (DER) } \\
& \mathrm{X} 4=\text { Profitability (ROA) }
\end{aligned}
$$

$$
\begin{array}{ll}
\mathrm{X} 5 & =\text { Maturity } \\
\mathrm{X} 6 & =\text { Auditor's Reputation } \\
\alpha & =\text { Constant } \\
\mathrm{b} & =\text { Regression Coefficient } \\
\mathrm{e} & =\quad \text { Standar Error }
\end{array}
$$

\section{Results and Discussion}


Data analysis in this study used the ordinal logistic regression method. Regression is used to determine the effect between the dependent variable and the independent variable. The dependent variable data is an ordinal scale, the measurement of which categorizes is divided into more than 2 categories. Tests are run to find the relationship between variables by testing the Model Fitting Information, Goodness of Fit, Pseudo R-Square, and Test of Parallel Lines.

\subsection{Model Fitting Information.}

Model Fitting Information is to find out how effective the variables used are by checking the suitability of the overall model with the overall relationship test, where the dependent variable determines the relationship between the independent variables and the group. From the Model Fitting Information table, it can be seen that the $2 \mathrm{LL}$ intercept only contains the constant 392.855 and the last $2 \mathrm{LL}$ reduces the $2 \mathrm{LL}$ number to 280.925 or decreases by 111.930 . The model, by adding variables, can predict the impact of CR, TATO, DER, ROA, Maturity, and Auditor Reputation. This is also seen in the final value of the significant variable, which is 0.000. This means that the model without independent variables has a statistically significant effect on the dependent variable because of $\mathrm{P}$-value $<\alpha_{i}(0.000<0.05)$.

\subsection{Goodness of Fit.}

Table 4. Model Fitting Information

\begin{tabular}{l|r|r|r|r} 
Model & $\begin{array}{c}-2 \text { Log } \\
\text { Likelihood }\end{array}$ & Chi-Square & df & Sig. \\
\hline Intercept Only & 392.855 & & & \\
\hline Final & 280.925 & 111.930 & 6 & .000 \\
\hline
\end{tabular}

Link function: Logit.

Goodness-of-Fit is to determine the suitability of the analysis model as a simultaneous parameter test. In the $G$ test, information will be obtained whether our model fits the data or not. The G-test results expect that the Chi-Square value is small so that it produces an insignificant probability $(p>0.05)$. The Chi-Square (Pearson) value is 1041.999, the Chi-Square (Deviance) value is 280.925, and significance values are 0.218 and 1.000 , respectively, where the $p$-value is $>0.05$. This shows the model fits the data.

Table 5. Goodness of Fit

\begin{tabular}{l|r|r|r} 
& Chi-Square & df & \multicolumn{1}{c}{ Sig. } \\
\hline Pearson & 1041.999 & 730 & .218 \\
\hline Deviance & 280.925 & 730 & 1.000 \\
\hline Link function: Logit.
\end{tabular}

\subsection{Pseudo R-Square.}

Pseudo R-Square is used to determine the strength of the relationship between the independent variable and the dependent variable and as an interpretation of the tendency ratio value formed by looking at one of Cox and Snell, Nagelkerke, or Mc Fadden values. Pseudo R Square testing is conducted to find out how much explanation the independent variable has to the dependent variable through the percentage obtained. The rest of the resulting percentage indicates that other factors explain the dependent variable. Pseudo R-squared value can be interpreted as an R-squared value of 0.285 (McFadden value). This value means that independent variables can explain $28.5 \%$, the remaining $71.5 \%$ can be explained by variables other than outside the research model.

Table 6. Pseudo R-Square

\begin{tabular}{ll} 
Cox and Snell & .635 \\
\hline Nagelkerke & .654 \\
\hline McFadden & .285 \\
\hline
\end{tabular}

\subsection{Test of Parallel Lines.}

Link function: Logit.

The parallel Lines test serves to assess whether the assumption is that all categories have the same parameters or not. The desired value in the parallel lines test is not significant, namely $p>0.05$. The significance value according to the Parallel Lines test is above 0.05 , which is 0.319 . This value can be interpreted that the model has the same parameters or the interaction between the independent variables using logit is the same for all logit equations. As a result, the selection of the link function is appropriate. 
Table 7. Test of Parallel Lines

\begin{tabular}{|c|c|c|c|c|}
\hline Model & $\begin{array}{l}-2 \text { Log } \\
\text { Likelihood }\end{array}$ & Chi-Square & df & Sig. \\
\hline Null Hypothesis & 280.925 & & & \\
\hline General & $235.173^{b}$ & $45.752^{c}$ & 42 & .319 \\
\hline \multicolumn{5}{|c|}{$\begin{array}{l}\text { The null hypothesis states that the location parameters (slope } \\
\text { coefficients) are the same across response categories. }\end{array}$} \\
\hline \multicolumn{5}{|c|}{ a. Link function: Logit. } \\
\hline \multicolumn{5}{|c|}{$\begin{array}{l}\text { b. The log-likelihood value cannot be further increased after } \\
\text { maximum number of step-halving. }\end{array}$} \\
\hline \multicolumn{5}{|c|}{$\begin{array}{l}\text { c. The Chi-Square statistic is computed based on the log-likelihood } \\
\text { value of the last iteration of the general model. Validity of the test } \\
\text { is uncertain. }\end{array}$} \\
\hline
\end{tabular}

Ordinal Logistic Regression to test the significant effect of the independent variable on the dependent variable. The research results can be seen as follows:

Table 8. Output Ordinal Logistic Regression

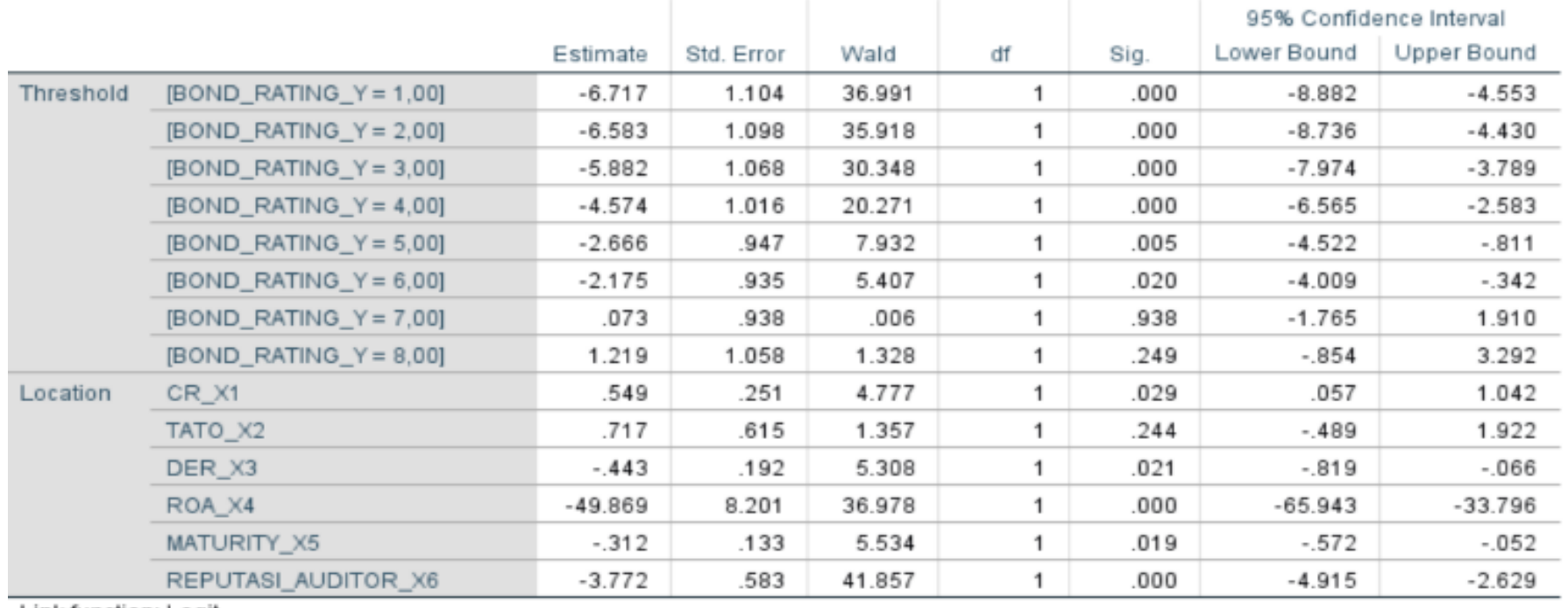

Link function: Logit.

Bond Rating is a rating given to bond issuers to indicate the risks associated with bond issuance. Bond ratings have a significant effect on the price and demand for certain bonds. The lower the rating, the greater the investment risk and the lower the investment value.

A downgraded firm credit rating can significantly impact bonds, as a low bond rating often results in poor business performance and liquidity problems for the firm. Bonds must be rated before being traded by a securities rating agency. In Indonesia, the bond rating agency is PT Pefindo, whose function is to provide an open, objective, independent, and reliable credit risk rating for debt securities to the public. PT Pefindo evaluates bonds according to sector risk, business risk, and firm financial risk through the issuing firm's annual financial report. The description is based on the interpretation of the results of the ordinal regression test as follows:

1. The Effect of liquidity on bond ratings. The test results show that the positive liquidity ratio with a proxy indicator of the current liquidity ratio (CR) is 0.549 , the significance level is 0.029 . A positive indicator means the higher the firm's liquidity, the higher the bond rating. A significance value smaller than 0.05 indicates that the liquidity variable has a positive and significant effect on bond ratings. The higher the level of liquidity, the greater the firm's ability to meet short-term commitments, and the more likely it is that the bonds will be considered investment-worthy. In particular, liquidity reflects that one's funds can be used to pay off all maturing debts. This is because the current assets owned by the firm can pay off the firm's current liabilities. The firm's ability to pay off short-term debt indirectly affects both long-term debts (payment of bonds). Therefore, a high level of liquidity will affect a good bond rating. The results of this study are in line with the results of previous studies (Faradi \& Supriyanto, 2015). 
2. The effect of activity on bond ratings. The TATO coefficient as a proxy for activity is 0.717 , the significance level is 0.244 , a positive coefficient means the larger the activity, the higher the bond rating. A significance value greater than 0.05 means that the activity variable does not affect bond ratings. The determination of a bond's rating cannot use activity as a benchmark because bond ratings are based on the firm's ability to pay debts, not asset size. Therefore, activity cannot be used as a measure of a high bond rating. Large companies can choose to borrow money, but there is no guarantee that the firm will pay off debts according to the repayment schedule. The results of this study are in line with previous research, in particular (Utami, Diah Anitasari, \& Endhiarto, 2017).

3. The effect of leverage on bond ratings. The coefficient of DER value as a proxy for the negative leverage variable is 0.443 , with a significant number of 0.021 , the significance level is lower than 0.05 which indicates that the leverage variable has a significant negative effect on bond ratings. An increase in DER will have a significant negative impact on bond ratings, because every time the firm's debt increases, investors are more alert. The lower the DER value, the higher the rating of the bonds issued. The results of this study are in line with (Hernando, Miranda, Luvena, \& Nurul, 2018), (Rudi \& Marsoem, 2019) and (Fadah, Ayuningtyas, Puspitasari, \& Yuswanto, 2020).

4. The Effect of profitability on bond ratings. The regression test results show that the firm's profitability as represented by ROA has a negative coefficient of 49.869 , a significance level of 0.000 , and a Wald statistic of 36.978 . The significance level is much lower than 0.05, indicating that the ROA variable has a significant negative effect on bond ratings. The results of this study are consistent with studies (Utami, Diah Anitasari, \& Endhiarto, 2017) and (Wibowo \& Linawati, 2020) which show that ROA has a negative and significant effect on bond ratings.

5. The Effect of maturity on bond ratings. The test results show a negative maturity coefficient of 0.312 , a significance level of 0.019. The significance level is much lower than 0.05 , indicating maturity has a significant negative effect on bond ratings. The results of this study are in line with research (Sakinah, Paminto, \& Kadafi, 2017) which shows that this maturity has a significant negative effect on bond ratings.

6. The Effect of auditor's reputation on bond ratings. The test results show a significant level of 0.000 , which is smaller than 0.05 , which indicates that the auditor's reputation variable has a significant negative effect, including bond rating obligations. The use of big KAP cannot be used as a benchmark because the bond rating is based on the ability of the bond issuer to pay its obligations, not the KAP used. This study differs from previous studies which found that auditor reputation had a significant positive effect on bond ratings, and auditor reputation had no effect on bond ratings.

\section{Conclusion}

Based on the results of testing the factors that can affect bond ratings in terms of accounting and non-accounting aspects, all listed corporate bonds traded on the Indonesia Stock Exchange (IDX) in 2019 sourced from Bloomberg using ordinal logistic regression, using the SPSS 25.0 program can be concluded as follows :

1. Liquidity with the Current Ratio (CR) proxy has a positive effect on bond ratings.

2. Activity with the Total Asset Turn Over (TATO) proxy do not affect bond ratings.

3. Leverage with the Debt to Equity Ratio (DER) proxy has a negative effect on bond ratings.

4. Profitability with the Return on Assets (ROA) proxy has a negative effect on bond ratings.

5. Maturity has a negative effect on bond ratings.

6. Auditor reputation has a negative effect on bond ratings.

The results of research on factors affecting bond ratings in 2019 were sourced from Bloomberg using ordinal logistic regression from accounting and non-accounting aspects. The accounting aspect is viewed from financial factors, namely liquidity, activity, leverage, and profitability as well as non-accounting aspects consisting of maturity and auditor reputation. The results of the research are expected to be used as information and evaluation material for the issuer and investors. What factors can affect the rating so that the parties are expected to manage and prevent risks that may arise? Based on the results of the research conducted, there are several managerial implications. The implications for firms from this research as input, evaluation in maintaining or obtaining an investment-grade bond rating. In the accounting aspect, the issuing firm can maintain the CR and DER ratios, while in the non-accounting aspect, the issuing firm can consider the maturity variable to minimize the risks that occur when issuing bonds.

The implications for investors. When investing in bonds, it is expected to choose Investment grade bonds by considering the factors that significantly affect the bond rating, namely $C R, D E R$, and Maturity, to minimize the default risk of the bonds they 
own. The implication for further researchers is to add/change the financial ratio factor used because it may influence bond ratings and include other non-financial factors such as coupons, transaction volume, and yield. Further researchers are expected to extend the observation period so that they can explain what independent variables consistently affect bond ratings.

\section{Limitations}

This research is a development of previous studies. However, there are still limitations, as follows:

1. Corporate bonds from publicly listed companies on IDX in 2019 were obtained from Bloomberg.

2. This research does not cover the financial sector (banking, finance, and insurance industries).

3. Corporate Bonds are only rated by Pefindo.

4. The accounting aspect in terms of financial ratios used as a measuring tool in influencing bond ratings only consists of $C R$, TATO, DER, and ROA ratios.

5. Non-financial aspects that are used as a measuring tool in influencing bond ratings are only Maturity and Audit Reputation.

\section{Suggestion}

Based on the conclusions and limitations of the research that has been presented in this study, the authors provide the following:

1. Suggestions to bond issuers are expected to maintain and improve the rating of bonds issued by determining the factors that are proven to be significant that can affect bond ratings, namely CR, DER and Maturity, so that they can guarantee what happens when they issue bonds. Bond issuers must pay attention to and anticipate several risks inherent in bonds, namely inflation, credit, and interest rates, to increase the bonds' rating.

2. Advice for investors to be able to distinguish between one bond and another which is better or worse, is to use a bond rating. In this study, investors are expected to expect the factors that are proven to be significant that affect bond ratings, namely CR, DER and Maturity. In addition, investors can pay attention to the Outlook on warning ratings, namely positive, stable and negative. A positive outlook means that the bond has the opportunity to undergo a rating upgrade in the future, the negative outlook is down and the outlook is stable.

3. Further researchers are expected to add/change the financial ratio factor used because it may influence bond ratings and include other non-financial factors such as transaction volume, coupons, inflation, and yields.

4. Future researchers are expected to use industries in the financial sector (banking, finance, and insurance industries).

5. Future researchers are expected to extend the observation period so that the research results can explain what independent variables consistently affect bond ratings.

\section{References}

[1] Akerlof, G. A. (1970). The Market for Lemons: Quality Uncertainty and the Market Mechanism. Quarterly. Journal of Economics, 84(3), 488500 .

[2] Arrow, K. J. (1963). Social Choice and Individual Value (II. New Haven ed.). Yale University Press.

[3] Asih, DP, E. N., \& Silalahi, S. (2016). Asih.(2016). Analisis Faktor-Faktor Yang Mempengaruhi Prediksi Peringkat Obligasi Pada Perusahaan Non-Keuangan Yang Terdaftar Di Bei Periode 2011-2013. JOM Fekon, 3(1 (Februari)), 74-88.

[4] Brigham, E. F., \& Houston, J. F. (2018). Dasar-Dasar Manajemen Keuangan (Empat Belas ed.). (N. I. Saliam, Trans.) Jakarta: PT. Salemba Empat.

[5] Fadah, I., Ayuningtyas, A., Puspitasari, N., \& Yuswanto, I. (2020). Analysis of financial and non-financial factors affecting bond ratings. IOP Conference Series: Earth and Environmental Science, pp. 1-9. doi:10.1088/1755-1315/485/1/012019

[6] Faradi, M. A., \& Supriyanto. (2015). Faktor-Faktor Yang Mempengaruhi Peringkat Obligasi Pada Perusahaan Non Keuangan Yang Terdaftar di Bursa Efek Indonesia. EKONOMI DAN BISNIS, 2(1), 13-28.

[7] Hernando, A., Miranda, E., Luvena, L., \& Nurul, A. (2018). Faktor-Faktor Determinan Peringkat Obligasi Perusahaan Go Public Non-Keuagan di Indonesia. Jurnal Riset Akuntansi dan Keuangan, 6(2), 173-186.

[8] Hery. (2016). Analisis Laporan Keuangan. Jakarta: PT. Gramedia Widiasarana Indonesia.

[9] Jensen, M. C., \& Meckling, W. H. (1976). Theory of the Firm: Managerial Behavior, Agency Costs and Ownership Structure. Journal of Financial Economics, 3(4), 305-360.

[10] Kasmir. (2016). Analisis Laporan Keuangan (Vol. Cetakan ke 7). Jakarta: PT Raja Grafindo Persada.

[11] Kieso, D. E., Weygandt, J. J., \& Warfield, T. D. (2015). Intermediate Accounting: IFRS Edition (2nd ed.). New Jersey: John Wiley \& Sons. Inc.

[12] Kontan. (2020). Ini perusahaan yang sempat gagal bayar dan berisiko gagal bayar di kuartal III-2020. Retrieved Januari 11, 2021, from https://investasi.kontan.co.id/news/ini-perushaan-yang-sempat-gagal-bayar-dan-berisiko-gagal-bayar-di-kuartal-iii-2020.

[13] Mardiyati, U., Utami, S. G., \& Ahmad, G. N. (2015). The Effect of Profitability, Liquidity, Leverage and Firm Size Toward Bond Rating On NonFinancial Institutionlisted In Indonesia Stock Exchange Period 2010-2014. Jurnal Riset Manajemen Sains Indonesia (JRMSI), 6(2), $579-598$.

[14] Megginson. (1997). Corporate Finance Theory. New York: Addison-Wesley Educational Publish Inc.

[15] Otoritas Jasa Keuangan. (2021). Peraturan Otoritas Jasa Keuangan No. 6/POJK.04/2021 tentang penerapan Manajemen Risiko Bagi Perusahaan Efek Yang Melakukan Kegiatan Usaha Sebagai Penjamin Emisi Efekdan Perantara Pedagang Efek Yang Merupakan Anggota Bursa Efek. Retrieved Mei 24, 2021 
[16] Parulian, \& Suprihatin, N. (2020). The Effect Of Company Profitability. Leverage. And Firm Size On Bond Ranking Of Banking Companies Registered On The Indonesian Stock Exchange (Idx) For The Period 2015 -2019. Journal of Reseacrh in Business, Economics, and Education, 2(4), 852-862.

[17] Pefindo. (2020). Pefindo's Corporate and Corporate Debt Securities Default Study 2007-2019. Retrieved Januari 11, 2021, from https://pefindo.com/fileman/file?file=545.

[18] Pratama, E., \& Andhitiyara, R. (2020). Pengaruh Debt Equity Ratio, Current Ratio, Maturity dan Size Terhadap Bond Rating (Studi Pada Perusahaan Perbankan Yang Terdaftar Di Bei Periode 2012-2017). 1(2), 53-79.

[19] Rosa, V. M., \& Musdholifah. (2016). The Effect of Leverage. Liquidity, Profitability, Coverage, Growth, and Firm Size with Auditor's Reputation as a Moderating to Bond Rating of Banking Firm. Jurnal Bisnis \& Manajemen., XVII(1), 48-57.

[20] Ross, S. A. (1977). The Determination of Financial Structure: The Incentive-Signalling Approach. The Bell Journal of Economics, 8(1), 23-40.

[21] Rudi, \& Marsoem, B. S. (2019). The Effect of Leverage, Liquidity, Profitability, and Size on Bond Rating in Financial Sector Companies in 2014-2018 Period. International Journal of Innovative Science and Research Technology, 4(12), 159-169.

[22] Sahabbudin, Z. A., \& Hadianto, B. (2020). The impact of the supervisory board on bond ratings of non-financial companies. Investment Management and Financial Innovations, 17(1), 15-23.

[23] Sakinah, P., Paminto, A., \& Kadafi, M. A. (2017). Analisis Faktor Keuangan dan Non Keuangan yang Mempengaruhi Prediksi Peringkat Obligasi (Studi empiris pada perusahaan penerbit obligasi yang terdaftar di Bursa Efek Indonesia periode 2012-2014). AKUNTABEL, 14(1), 69-78.

[24] Sihombing, P. (2018). Corporate Financial Management (Cetakan ke 1 ed.). Bogor: PT Penerbit IPB Press.

[25] Utami, E. S., Diah Anitasari, D., \& Endhiarto, T. (2017). Determinants of Corporate Bond Rating in Indonesia: Additional Evidence. Review Of Management And Entrepreneurship, 1(2), 27-33.

[26] Wibowo, A. E., \& Linawati. (2020). Pengaruh Likuiditas, Profitabilitas Dan Leverage Terhadap Peringkat Obligasi Perusahaan di Indonesia. JURNAL RISET MANAJEMEN, 7(1), 143-152.

[27] Wijaya, D. (2017). Manajemen Keuangan Konsep dan Penerapannya. Jakarta: PT. Grasindo. 